\title{
Characterization of Patients with Inguinal Hernia Ambulatory Surgical Treatment
}

\author{
Pedro Rolando Lòpez Rodrìguez ${ }^{1^{*}}$ (D), Olga Caridad Leòn Gonzalez ${ }^{2}$ (D), Jorge Satorre \\ Rocha $^{3}$ (D) Eduardo Castillo Garcia ${ }^{3}$ (D) Luis Marrero Quiala ${ }^{3}$ (D) M Elisa Puentes Rizo ${ }^{4}$ (D) \\ and Lais Angelica Ceruto Ortiz ${ }^{5}$ (iD
}

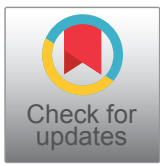

${ }^{1}$ Consultant Professor, General Surgery, Auxiliary Researcher, General Teaching Hospital "Enrique Cabrera", Havana, Cuba ${ }^{2}$ Auxiliary Assistant, General Surgery, Auxiliary Researcher, General Teaching Hospital "Enrique Cabrera", Havana, Cuba ${ }^{3}$ Assistant Professor, General Surgery, Aggregate Investigator, General Teaching Hospital "Enrique Cabrera", Havana, Cuba ${ }^{4}$ Associate Researcher, Auxiliary Teacher in MGI, General Teaching Hospital "Enrique Cabrera", Havana, Cuba ${ }^{5}$ Resident, General Surgery, General Teaching Hospital "Enrique Cabrera", Havana, Cuba

*Corresponding author: Dr. Pedro Rolando Lòpez Rodrìguez, Consultant Professor, General Surgery, Auxiliary Researcher, General Teaching Hospital "Enrique Cabrera", Continental Street No. 152 between D'Stramples Street and Goicuria Street, Sevillano, 10 de Octubre, Havana, Cuba, Tel: +53-76413062

\begin{abstract}
Summary
Introduction: The surgical treatment of inguinal hernia has increased in the last decade and its prevalence is not known.

Objective: Characterization of patients with inguinal hernia ambulatory surgical treatment.

Methods: An observational, descriptive and prospective study of 972 patients with the diagnosis of inguinal hernia was performed, which were operated on an outpatient basis in the General Teaching Hospital "Enrique Cabrera" since January 2009 to December 2020. Emergency operated patients were excluded.

Results: The highest incidence of inguinal hernia was found between the ages of 60 and 80 years. Indirect right inguinal hernia appeared more frequently. Desarda's anatomic surgical technique was the most applied in $410(42.1 \%)$ of the cases and Lichtenstein's hernioplasty with $224(23.0 \%)$ followed in frequency. There were a total of $5(0.5 \%)$ recurrences. Local anesthesia was applied in $828(85.2 \%)$ of the patients, on an outpatient basis they were $100 \%$. The total complications were 42 (4.3\%).

Conclusions: Surgical treatment of inguinal hernia on an outpatient basis is an appropriate process. It creates comfort in patients, decreases the risk of hospital infection, and reduces waiting lists and hospital costs.
\end{abstract}

\section{Keywords}

Inguinal hernia, Outpatient treatment, Hospital costs

\section{Introduction}

The inguinal hernia is known since man adopted the erect position, so it is one of the most frequent conditions. Its history is as old as humanity itself. It is a topic of interest not only for historians, but for compulsory knowledge for anatomists and surgeons. The first description of hernia reduction dates from the time of Hammurabi in the Egyptian papyri [1]. According to the Papyrus of Ebers, dating from $1560 \mathrm{BC}$, the hernia is a tumor in the genitals in which the intestines move. It is the protrusion of an organ of the abdominal cavity through a natural or acquired orifice. Hesinten, in 1794, establishes a Differentiation between hernias treated by direct and indirect inguinal sacs. It is important to note that this had already been demonstrated by Cospar Stromary in 1599, who insisted on the uselessness of the sacrifice of the testicle in direct hernias [2].

In 1804, Cospar described the transverse fascia and pointed out that this layer and not the peritoneum and external oblique aponeurysis was the main barrier to avoid herniation. He also defined direct hernia as a defect that occurs through the Hesselbach triangle [3].

With the passing of time came the modern era of

Citation: Rodrìguez PRL, Gonzalez OCL, Rocha JS, Garcia EC, Quiala LM, et al. (2021) Characterization of Patients with Inguinal Hernia Ambulatory Surgical Treatment. Clin Med Rev Case Rep 8:345. doi. org/10.23937/2378-3656/1410345

Accepted: April 28, 2021: Published: April 30, 2021

Copyright: (C) 2021 Rodriguez PRL, et al. This is an open-access article distributed under the terms of the Creative Commons Attribution License, which permits unrestricted use, distribution, and reproduction in any medium, provided the original author and source are credited. 
hernia surgery, which began with the discovery of antisepsis by Lister, studies on anesthesia, knowledge of the normal physiology of the inguinofemoral region, the introduction of antibiotics and the best understanding of the repair process tissue and scarring. Everything was linked to the emergence of better surgical methods as shown by the work of Henry and Marcy in the USA. UU by E. Bassini in Italy [4].

We must point out that from the second half of the eighties a new era began, characterized by the use of prosthetic meshes and patches with which better results are obtained in this surgery. Among the materials used is polypropylene, which is biocompatible with high tensile strength, flexible, impermeable to water and resistant to high temperatures, which makes it sterilizable [5].

The application of outpatient surgery has the following advantages: Altering only alters the patient's life, which receives more individual attention; the anxiety of the patient is attenuated; costs are reduced; decreases the risk of hospital infection and disability; It also facilitates the return to work. All this contributes to improve the quality of the services.

One of the most important aspects of this type of surgery is the application of local anesthesia that improves the cost-benefit ratio of the procedure, decreases the use of hospital beds and allows the patient's collaboration if necessary.

The objective of this study is to evaluate the results of outpatient surgical treatment of this entity, describe the population, techniques and complications from January 2009 to December 2020.

\section{Methods}

A cross-sectional, prospective, descriptive observational study of patients operated out of inguinal hernia was performed in the surgery service of the "Enrique Cabrera" General Teaching Hospital in the period from January 2009 to December 2020.

The universe consisted of patients operated on inguinal hernia in the surgery service of the General Teaching Hospital "Enrique Cabrera" from January 2009 to December 2020. The sample consisted of patients operated on inguinal hernia on an outpatient basis by the Group. Basic Work (GBT) No. 1 in the surgery service of said hospital in the aforementioned period.

This study included all patients aged 18 years or older, ASA III or lower risk of anesthesia, obesity not over $50 \%$ overweight and carriers of the disease under study. Patients with associated, decompensated and overweight diseases greater than $50 \%$ of their body weight were excluded.

The hernia classification used was that of Lloyd M. Nyhus, American surgeon in 1991, who describes a publication based on anatomical criteria.
Table 1: Sex, location and classification of hernias.

\begin{tabular}{|l|l|l|}
\hline Sex & No & $\%$ \\
\hline Female & 104 & 10.7 \\
\hline Male & 868 & 89.3 \\
\hline Location & \multicolumn{2}{|l|}{} \\
\hline Right & 484 & 49.8 \\
\hline Left & 386 & 39.7 \\
\hline Bilateral & 102 & 10.5 \\
\hline Variety & & \\
\hline Indirect & 605 & 62.2 \\
\hline Direct & 325 & 33.4 \\
\hline Mixed & 42 & 4.4 \\
\hline Classification of Nyhus & & \\
\hline Type I & 0 & - \\
\hline Type II & 438 & 40.8 \\
\hline Type IIla & 296 & 27.4 \\
\hline Type IIlb & 256 & 24.0 \\
\hline Type IIIc & 0 & - \\
\hline Type IV & 84 & 7.8 \\
\hline & & \\
\hline
\end{tabular}

Type I: Indirect inguinal hernia with normal internal ring.

Type II: Indirect inguinal hernia with enlargement of the inner ring.

Type III: Contemplate in turn three possibilities:

Type Illa: Direct inguinal hernia; Type IIlb: Mixed inguinal hernia or in trousers; Type III c: Femoral hernia.

Type IV: All recurrent hernias.

Type IV: All recurrent hernias [6].

The principles related to the code of ethics were followed, according to the Helsinki declaration. The security and confidentiality of the information was guaranteed.

\section{Results}

It is observed that the most frequent location of the inguinal hernia was the right side with 484 patients for the $(49.8 \%)$ of the total, of which $62.2 \%$, were indirect. The average age of the patients included in the study was 57.4 years. There were five recurrent hernias (0.5\%). According to the Nyhus classification, there were a total of 972 patients with hernias belonging to types II and III $b$, which were the most frequent (Table 1).

The operative techniques most used in inguinal hernias are shown in Table 2. Non-prosthetic techniques were applied and of these the most performed was the Mohan P. Desarda technique in 410 patients (42.1\%). Within the prosthetic techniques the most applied was that of Lichtenstein, in 224 patients (23.0\%).

Table 3 shows the most used anesthetic procedures. Local anesthesia was applied in 828 patients $(85.2 \%)$ of 
Table 2: Relationship between relied techniques and recurrence.

\begin{tabular}{|l|l|l|l|l|}
\hline Techniques & No & $\%$ & Recurrence & $\%$ \\
\hline Shouldice & 6 & 0.6 & & \\
\hline Zimmerman I & 10 & 1.0 & & \\
\hline Madden & 8 & 0.8 & 1 & 12.5 \\
\hline Mc Vay & 20 & 2.0 & & \\
\hline Goderiche & 8 & 0.8 & 1 & 12.5 \\
\hline Bassini & 10 & 1.0 & & \\
\hline Camayd & 2 & 0.2 & & \\
\hline Lotheissen Mc Vay & 6 & 0.6 & & \\
\hline Halsted & 6 & 0.6 & & \\
\hline Desarda & 410 & 42.1 & 2 & \\
\hline Plug de Rutkow & 2 & 0.2 & & \\
\hline Marcy & 12 & 1.2 & & \\
\hline Rives & 22 & 2.2 & & \\
\hline Lichtenstein & 224 & 23.0 & 1 & \\
\hline Rutkow-Robbins & 8 & 0.8 & & \\
\hline Desarda Modificada & 212 & 22.0 & & \\
\hline Zimmerman II & 6 & 0.6 & & \\
\hline Total & 972 & 100.0 & 5 & \\
\hline & & & & \\
\hline
\end{tabular}

Table 3: Analgesic Procedures.

\begin{tabular}{|l|l|l|}
\hline Procedures & No & $\%$ \\
\hline Local Anesthesia & 828 & 85.2 \\
\hline Spinal Anesthesia & 130 & 13.4 \\
\hline General and Endotracheal Anesthesia & 7 & 0.7 \\
\hline Acupuncture Anesthesia & 0 & - \\
\hline Peridural Anesthesia & 3 & 0.3 \\
\hline General Endovenous Anesthesia & 4 & 0.4 \\
\hline Total & 972 & 100.0 \\
\hline
\end{tabular}

Table 4: Diseases and Associated Conditions.

\begin{tabular}{|l|l|l|}
\hline $\begin{array}{l}\text { Associated Diseases and } \\
\text { Associated Conditions }\end{array}$ & No & $\%$ \\
\hline Ischemic Cardiopathy & 30 & 3.5 \\
\hline Arterial Hypertension & 155 & 19.0 \\
\hline Diabetes Mellitus & 38 & 4.0 \\
\hline Umbilical Herniorraphy & 13 & 1.3 \\
\hline Femoral Herniorraphy & 6 & 0.6 \\
\hline Incisional Herniorraphy & 3 & 0.3 \\
\hline Eversiòn of Vaginal & 3 & 0.3 \\
\hline Total & 248 & 25.5 \\
\hline
\end{tabular}

the total, followed by spinal anesthesia or spinal anesthesia in 66 patients $(8.8 \%)$.

The associated diseases are shown in Table 4, with the prevalence of arterial hypertension 155 patients (16.0\%) and the conditions associated with umbilical hernia with 13 patients (1.3\%).

The Table 5 shows the distribution of complications
Table 5: Complications.

\begin{tabular}{|l|l|l|}
\hline Complications & No & \% \\
\hline Seromas & 13 & 1.3 \\
\hline Recurrences & 5 & 0.5 \\
\hline Hematomas & 6 & 0.6 \\
\hline Orchitis & 5 & 0.5 \\
\hline Bladder Piercing & 2 & 0.2 \\
\hline Infection of the surgical site & 11 & 1.1 \\
\hline Total & 42 & 4.3 \\
\hline
\end{tabular}

in patients undergoing local anesthesia in the period from January 2009 to December 2020, at the "Enrique Cabrera" General Teaching Hospital.

It is observed that the seroma was the complication that most frequently presented 13 patients $(1,3)$, followed by infection of the surgical site 11 patients $(1,1)$ and in total 42 complicated patients $(4,3)$.

\section{Discussion}

The results obtained in this series are consistent with those obtained by different authors and differ from others who point out the primacy of inguinal hernia in younger patients. There was predominance of males, results similar to those referred in several studies on the subject $[7,8]$.

According to experts in the field, up to $25 \%$ of males and only $2 \%$ of females will develop inguinal hernia at some point in their life. This fact has been related to the descent of the testicle, with a greater thickness of the spermatic cord and with a lower obliquity of the inguinal canal in man.

In the opinion of the authors, who share the Goderich criterion [8], when other conditions are concomitant, patients should be treated before having herniorrhaphy to avoid postoperative discomfort and the increase in the recurrence rate. There are also criteria that the McBurney incision during appendectomy is related to the appearance of inguinal hernia. In the present work the ages ranged between 60 and 80 years, which is similar to the literature reviewed.

The right inguinal hernia was the most frequent, as well as the indirect variety on both sides. It was also observed that the highest number of hernias corresponded to variety II, from the Nyhus classification $[6,9](144$ patients) and variety III b (103 patients).

Every surgeon who frequently intervenes in patients with a hernia of the inguinal region knows that there are innumerable surgical techniques, to which advantages and disadvantages are indicated.

The purpose is to reduce complications and, above all, to avoid recurrences [10]. There are so-called classical (anatomical) techniques that repair the defect of the inguinal wall with the patient's own tissues and, the socalled prosthetic techniques, which use synthetic mate- 
rials that have had a great development in recent decades and whose application always leads to the same purposes as anatomical.

It was observed that the most used anatomical technique was that of Mohan P. Desarda, followed by the Lichtenstein technique. For some years now, a basic working group of our surgical service has applied the anatomical technique of Professor Desarda and has obtained good results. This technique, as pointed out by its creator, has some advantages, among which are its easy learning and execution, available to residents and surgeons not specialized in the treatment of this disease $[11,12]$. The technique provides a posterior wall of the canal Strong inguinal, mobile and physiologically active. When not using the mesh (foreign body) the fibrosis is minimal or does not exist, there is no rejection to foreign body and the postoperative pain on the fifth day of the operation is less than with the techniques that use prosthesis. With the application of local anesthesia, to carry out the outpatient procedure in these patients, the complications were minimal $[13,14]$.

By carefully analyzing the number of recurrences and the level of preparation of the acting surgeon, it was found that all patients operated by residents were helped by specialists, who correct the possible defects of the operative procedure, this contributes to the technical improvement and the increase of skills and skills during the surgical act. In Cuba, this has greater relevance, since the teaching care system guarantees the integral surgical training of the resident, an aspect not comparable with what is referred to in the international medical bibliography, where this centralization does not exist [15-17].

In this series there were no deaths. None of the operated patients had the need to change their occupation, or difficulty to get into their job before 60 days. It is important to highlight the late complications of this procedure, such as the rejection of the bioprosthesis and the appearance of fistulas and granulomas.

We must point out that in this center the various techniques of hernia repair, facial and aponeurotic are applied, with the use of prosthetic meshes or without these, with good results, especially in the repair of hernias with tension-free facial techniques, since anatomically it is more physiological, compared at the same time, with national and international studies [18].

Taking into account the large number of patients operated during the study period, the savings contributed to the hospital by the reduction of occupied beds, the decrease in the cost of materials and medicines, the faster recovery of patients and the incorporation into their social environment and labor. It is concluded that outpatient surgery with local anesthesia plus sedation is a beneficial method for patients and hospital institutions and this is shown in the results in this case [19-25].

\section{Conclusions}

The male sex, the right location of the hernia and the type II of Nuhys predominated the herniorrhaphy Desarda, the local nestesia and serona as a complication were more frequent, being the hernia recurrence in our work was $0.5 \%$. As summary we can say that the treatment of inguinal hernia on an outpatient basis results in satisfactory results.

\section{Conflicts of Interest}

The authors do not declare having conflicts of interest.

\section{References}

1. Borquez P, Garridol Manterola C, Pena P, Schlageter C, Orellana J, et al. (2010) Estudio de fibras colágenas y elástica del tejido conjuntivo de pacientes con y sin hernia inguinal primaria. Rev Med Chile 131: 1273-1279.

2. Rodríguez Ortega MF, Cardenas-Martinez G, Lopez-Castaneda (2005) Evolución histórica del tratamiento de la hernia inguinal. Cirugía y Cirujanos 71.

3. Woods BB, Neumayer L (2010) Open repairof inguinal hernia: An evidence-based review. Surg Clin North Am 88: 139-155.

4. Armas Pérez BA, Reyes Balseiro ES, Dumenigo Area O, González Monacal OR (2009) Hernias inguinales bilaterales operadas con anestesia local mediante hernioplastia de Lichtenstein. Rev Cubana Cir 48.

5. Lòpez Rodrìguez $P R$, Pol Herrera $P G$, Leòn Gonzàlez $O C$, Satorre Rocha JA, Garcia Castillo E (2016) Tratamiento quirùrgico ambulatoria en pacientes con hernia inguinal. Revista Cubana de Cirugía 55.

6. Nuhys LM (1993) Individualization of hernia repair: A new era. Surgery 114: 1-2.

7. Magdaleno Garcia M, Robles Placencio J, Melendes Delgado MD (2017) Factores relacionados con el alta precoz tras la reparación de hernia inguinal. Cir Mayor Ambul 22: 3-9.

8. Doménico Arias $\mathrm{O}$, de Armas Pérez B, Martínez Ferra G, Gil Hernández A (2007) Hernioplastia inguinal del Lichtenstein: la mejor opción. Rev Cubana Cir 46: 28-33.

9. Goderich Lalan JM, Goderich Lopez D (1998) Herniorrafia inguinal por sobrecapa de fascia transversalis. Rev Cubana Cir 37: 41-46.

10. Van ven RN, Van Wessem KJ, Halm JA, Simona MP, Plaiser PW, et al. (2007) Patent process us vaginalis in the adult as a risk factor for the occurrence of indirect inguinal hernias. Surg Endosc 21: 202-205.

11. Abraham Arap J (2009) Hernias inguinales y crurales (hernia de la ingle). Rev Cubana Cir 48.

12. Abraham Arap JF, Mederos Curbelo ON, García Gutiérrez A (2009) Características generales de las hernias abdominales externas. En: García Gutiérrez A, Pardo Gómez G, Cirugía. Tomo 3. La Editorial Ciencias Médicas, Habana, 410.

13. Morales Conde S, Barreiro Morandeira F (2009) Cirugía de la hernia: nuevos conceptos, nuevas perspectivas. Cir Esp 83: 165-166.

14. López Rodríguez $\mathrm{P}$, Pol Herrera $\mathrm{P}$, León González $\mathrm{O}$, Muñoz Torres JC (2010) Dolor y costos hospitalarios en 
la reparación de la hernia inguinal primaria: Lichtenstein frente a Desarda. Rev Cubana Cir 49.

15. Maraboto AC (2010) Manejo anestésico del paciente que será sometido a una hernioplastia. DF: El Manual Moderno, México, 93-101.

16. Medical Research Council Laparoscopic Groin Hernia Tria Group (2010) Cost-utility analysis of open versus laparoscopic groin hernia repair: results from a multicenter randomized clinical trial. Br J Surg 88: 653-661.

17. Butte JM, León F Van Sint Jan N, Hevia C, Zúñiga A, Ibáñez L, et al. (2010) Hernioplastia inguinal con técnica Prolene hernia system. Evaluación de los resultados a largo plazo. Rev Chl Cir 59: 421-424.

18. Arowolo OA, Agbakwuru EA, Adisa AO, Lawal OO, Ibrahim $\mathrm{MH}$, et al. (2011) Evaluation of tension-free mesh inguinal hernia repair in Nigeria: a preliminary report. West Afr $J$ Med 30: 110-113.

19. Desarda MP, Ghosh A (2006) Comparative study of ppen mesh repair and Desarda's no-mesh repair in a District Hospital in India. East and Central African Journal of Surgery 11: 1-6.
20. Desarda MP (2009) No mesh inguinal hernia repairs with continuos absorbable sutures: A dream or reality? (A study of 229 patients). The Saudi Journal of Gastroenterology 14: 122-127.

21. López Rodríguez PR, Pol Herrera P, León González OC, Satorre Arocha J (2013) Nuestra experiencia de diez años con la herniorrafia de Mohan P. Desarda. Rev Cub Cir 52: 1-5.

22. Recart $A$ (2017) Cirugìa mayor ambulatoria .Una nueva forma de la medicina quirúrgica. Rev Med Clin Las Condes 28: $682-690$.

23. Capitan Valvay JM, Gonzalez Vinagre S, Barreiro Morandeira $F$ (2018) Cirugìa mayor ambulatoria: Donde estamos y a donde vamos. Rev Española Cir 96: 1-2.

24. Alonso Rodríguez Y, López Martin JE, Gil Soto R, Hernández Nuñez A, Hernández Pérez R (2020) Caracterización de los pacientes con hermia inguinal operados por la Técnica de Lichtenstein. Rev Cubana Cir 59: e_1022.

25. López Rodríguez PR, Danta Fundora LM, León González OC, Satorre Rocha JA, Garcia Castillo E, et al. (2018) Herniorrafia de Mohan P. Desarda modificada en la reparación de la hernia inguinal sin prótesis. Rec Cubana Cir 57. 